\title{
Journals Supporting Terrorism Research: Identification and Investigation into Their Impact on the Social Sciences
}

\author{
Daryl R. Bullis and Richard D. Irving
}

A citation analysis of two preeminent terrorism journals (Terrorism and Political Violence and Studies in Conflict and Terrorism) was used to identify 37 additional social science journals of significant importance to terrorism research. Citation data extracted from the Web of Science database was used to investigate the impact of the two journals on the social science journal literature. The impact of the two journals was also analyzed in terms of SSCI subject categories. This study could provide useful information for collection development librarians interested in the social sciences.

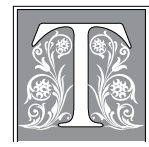

he events of September 11, 2001, changed everything. This refrain has been uttered repeatedly over the last ten years by the moving forces in our private and public institutions as they adapt their policies and procedures to a new perception of reality in the post-9/11 world. Now, ten years after the event, it may be time for academic libraries to assess the implications the changes are making on their collection development activities regarding terrorism literature, specifically the impact on the dissemination patterns of academic research as represented in the journal literature.

In this article, the authors examined the terrorism research literature as it is presented in social science academic journals with two purposes: to identify a core list of social science journals engaged in supporting terrorism research, and to determine whether there was a discernible pattern to the terrorism literature and its impact on the broader social science literature. The findings have implications for academic library collections.

\section{Background}

Academic research regarding terrorism precedes 9/11. In 1997, Reid provided an overview of the development of terrorism as a research field in the United States in which she noted that, after a period of few terrorism research studies published in the 1960s, the research started to proliferate in the 1970s accompanied by the development of a group of researchers focused on terrorism. ${ }^{1}$ Gordon and Silke, in separate studies published almost a decade

Daryl R. Bullis is Bibliographer for Music, Russian E East European Studies, and Slavic Languages $\mathcal{E}$ Literatures and Richard D. Irving is Bibliographer for Public Administration E Policy and Political Science, both at University at Albany, SUNY; e-mail:dbullis@uamail.albany.edu, rirving@uamail.albany.edu. The authors gratefully acknowledge Benjamin Andrus, Binghamton University, for sharing his expertise in using the Web of Science database." (C) 2013 Daryl R. Bullis and Richard D. Irving, Attribution-NonCommercial (http://creativecommons.org/licenses/by-nc/3.0/) CC BY-NC 
later, agreed that the increase in terrorism literature preceded $9 / 11$. Both noted that research in the field was undoubtedly stimulated by $9 / 11$ but cautioned that it was unclear that the accelerated rate would be maintained. Much of the work attempting to give structure to the study of terrorism and identifying the major research foci and researchers has taken place over the last twenty years. ${ }^{2}$ In 2007, following up on Reid's previous research, Reid and Chen traced the development of terrorism as a research field and identified conceptual areas as well as key researchers and their publications. ${ }^{3}$ Silke has also contributed to this area most notably in a study in which he used two preeminent journals in the field to identify key researchers, their academic disciplines, and institutional affiliations. ${ }^{4}$

Whereas Reid's research has emphasized the many facets and mutidisciplinary nature of terrorism research, another emphasis, represented by Gordon, has advocated for developing a more coherent research field, noting in a series of publications that terrorism research was characterized by a broad dispersion of the publishing sources at its periphery and that much of the research was conducted by transient researchers who published perhaps only a few articles and then moved on to other research topics. Of particular interest to this study were her 2005 and 2007 articles in which she lamented the insufficient coverage of the core terrorism literature in the Social Sciences Citation Index (SSCI) database. ${ }^{5}$ In the earlier article, she noted that the two key journals, Terrorism and Political Violence and Studies in Conflict and Terrorism, were not covered in SSCI. That particular problem has since been addressed since Terrorism and Political Violence became fully covered in SSCI in 2002 and Studies in Conflict and Terrorism in 2006. Nevertheless, Gordon continued to argue that the failure to develop a core literature, core group of researchers, and theories impeded the development of terrorism studies as an autonomous discipline with its own academic departments, scholarly journals, and professional academic associations. ${ }^{6}$

While researchers have devoted more attention to the study of terrorism and its related fields since $9 / 11$, there has also been an increase in the number of educational institutions granting postbaccalaureate degrees relating to the study of terrorism. A search in Peterson's Graduate and Professional Programs Online showed that seven universities currently offer master's level degree programs that allow degree candidates in more traditional disciplines to specialize in some aspect of terrorism. Examples of degrees currently offered in both traditional and online venues are Master of Science in Criminal Justice, Master of Science in Psychology, Master of Public Administration, Master of Public Health, Master of Arts in International Relations, and Master of Arts in Diplomacy, all with an opportunity to specialize in the study of terrorism.

In addition to these formal degree programs, there are examples of institutions granting certificate programs in terrorism studies, such as the M.A. Certificate Program in Terrorism Studies at The Center on Terrorism at John Jay College of Criminal Justice and the Graduate Certificate in Terrorism Studies at the National Consortium for the Study of Terrorism and Responses to Terrorism (START) at the University of Maryland. A search in the Gale Digital Library's Research Centers Directory indicated that the number of university affiliated research centers whose research activity on the study of terrorism and related fields is growing. No fewer than 32 universities in the United States each host at least one research center or foundation that focus on some aspect of terrorism, such as the START Consortium at UMD mentioned above. It would be expected that the libraries at these universities would direct at least some of their collections activities toward the acquisition of the appropriate monographs and serials relating to terrorism.

Terrorism has not yet been established as an independent discipline, but there is 
growing momentum to satisfy the need for professionals and scholars with formal training in the study of terrorism. Of central importance to the present study was the identification of Terrorism and Political Violence and Studies in Conflict and Terrorism as the two preeminent research journals in the field by both Silke and Gordon. The fact that both journals are currently fully covered in SSCI further supports their importance. The intent of the present study's authors was to examine the citation patterns surrounding these two journals and then to develop a core list of academic journals that might provide some guidance to collection development librarians.

\section{Literature Review}

While there has been an abundance of studies published regarding the development of core journal lists for various academic disciplines, the authors did not find any studies focusing on terrorism research. Core journal studies appear in both the library science literature and in the journal literature of other academic disciplines. Studies published in non-library science journals tend to emphasize the development of core lists identifying the most prestigious journals in the field. For example, Giles and Garand published a study ranking political science journals with the express purpose of providing political science researchers with guidance regarding the most prestigious studies to publish for career advancement. ${ }^{7}$ Core studies appearing in library science journals may also be concerned with identifying the most prestigious journals in a particular field. However, since the purpose of these studies may be to provide information to collection development librarians as to what journals should be in their collections, they may employ other criteria such as the needs of local faculty, student use, cost per use, and availability through interlibrary loan. The present study, which makes use of citation data, may be helpful for collection development librarians in that it identifies social science journals that are not necessarily solely dedicated to terrorism studies but are still important to terrorism researchers.

In a 2003 article, Corby examined the various methodologies used to develop core journal lists as well as the limitations associated with the various methods. ${ }^{8}$ She credited Doreian for his conclusion that two general strategies predominated studies concerned with identifying the most prestigious journals: subjective studies that rely on some type of opinion survey and objective studies that make use of citation data. Some studies may combine both strategies in their assessments. ${ }^{9}$ However, Corby found that studies using different strategies have yielded contradictory results as have some studies making use of both strategies. Her general conclusion was that, in designing a journal study, researchers need to be flexible regarding the methodology, taking into account both the purpose of the study and the measurable data that are available. In 2007, Nisonger provided a review of ten methodologies used by librarians to develop core journal lists: "subjective judgment, use, indexing coverage, overlapping library holdings, citation data, citation network/co-citation analysis, production of articles, Bradford's Law, faculty publication data, and multiple criteria methods." ${ }^{10} \mathrm{He}$ analyzed each method using examples to highlight the theoretical and practical problems associated with each. His conclusion was that core journal lists could be helpful in making collection management decisions but should not be used as the "sole decision-making criterion."

Despite limitations, core lists can provide some guidance for collection development especially when dealing with an emerging research area such as terrorism studies. Several studies have previously used a strategy, such as that used in the present study, in which a few key journals were identified in a field and then citation data based on articles in the key journals were used to identify other core journals. Budd, in part of his 1990 study of citation patterns, derived a list of the twenty most-cited journals in the field of higher 
education using citation data from three key journals in the field. ${ }^{11}$ Weissinger conducted a study using citation data from two prominent black studies journals and identified journals associated with more traditional disciplines, such as sociology, that were cited frequently enough to be important to black studies scholars. ${ }^{12}$ Similarly, the authors of the present study used citation data from two prominent terrorism studies journals and identified journals from social science disciplines that are important to terrorism scholars. The present study takes a step beyond Wessinger and Budd by examining citations appearing in social science journals making reference to articles appearing in either Studies in Conflict and Terrorism or Terrorism and Political Violence to assess the impact of terrorism research throughout the social sciences.

\section{Methodology}

While Reid identified the key terrorism researchers and their major research foci, both Gordon and Silke indicated that the terrorism research was composed to a great extent of transient authors whose academic roots were dispersed throughout the social sciences. Lacking a professional association or other common institutional membership, it would be difficult to identify a group of terrorism scholars to consult regarding their opinion of the core journals in the field. Since Terrorism and Political Violence and Studies in Conflict and Terrorism have been identified as the preeminent scholarly journals in terrorism studies, a citation strategy similar to that employed by Budd and Weissinger offered a more promising strategy for developing a core list.

Terrorism and Political Violence is a refereed journal published since 1989 by Routledge and had been published quarterly until 2011 when the publishing schedule changed to five times per year. It has been fully covered in SSCI since 2002. Ulrich's International Periodical Directory provides the following description: "Publishes studies of various related forms of violence by rebels and by states, on the links between political violence and organized crime, protest, rebellion, revolution, and human rights." Studies in Conflict and Terrorism is a refereed journal published since 1992 by Taylor \& Francis and was formed out of a merger between the journals Conflict and Terrorism. It has been published monthly since 2007 and has been fully covered in SSCI since 2006. Ulrich's International Periodical Directory provides the following description: "Aims to cast new light on the origins and implications of conflict in the 21st Century and to illuminate new approaches and solutions to countering the growth and escalation of contemporary sub-state violence." Neither journal is an official publication of a scholarly society.

The authors collected citation data for each journal for the years 2007, 2008, and 2009. The authors chose three years to get an adequate sample size. Gordon's and Silke's research both indicated a wide dispersion of the relevant literature in the social sciences and the present authors wanted to obtain a broad enough sample to guard against anomalies. Limitations in SSCI coverage prevented the authors from extracting complete data from earlier years for the citing references portion of this study.

\section{Methodology: Cited References}

The first part of this study involved collecting data for social science journals cited in Terrorism and Political Violence and Studies in Conflict and Terrorism for each of the three years. The authors included citations appearing in research notes and book reviews as well as in research articles. Data collection was primarily focused on cited journals fully covered in SSCI in 2009, although some data was collected for journals not covered in SSCI. ${ }^{13}$ Despite criticism and challenges from Elsevier's Scopus database, SSCI is still widely recognized as the most authoritative citation source for social science research literature. Journal Citation Reports (JCR) provides cited reference data for 


\begin{tabular}{|l|c|c|c|}
\hline \multicolumn{4}{|c|}{ TABLE 1 } \\
\hline & TPV $^{\text {a }}$ & SCT $^{\mathrm{b}}$ & TPV/SCT Combined \\
\hline Total & 655 & 1,299 & 1,954 \\
\hline Without Self-cites & $505(77 \%$ of total $)$ & $1,105(85 \%$ of total $)$ & $1,610(82 \%$ of total $)$ \\
\hline $\begin{array}{l}\text { Without Self-cites and } \\
\text { Cross-cites }\end{array}$ & $425(65 \%$ of total $)$ & 997 (77\% of total) & $1,422(73 \%$ of total) \\
\hline a TPV is Terrorism and Political Violence; ${ }^{\mathrm{b}}$ SCT is Studies in Conflict and Terrorism \\
\hline
\end{tabular}

SSCI journals both in microfiche format and through the Web of Science database. However, neither format provides a complete list of all cited references. Therefore, the authors collected data by manually checking all cited references as they appeared in each article. A cited article was counted only once per citing article even if it was cited multiple times in that article.

\section{Methodology: Citing References}

The second part of this study involved collecting data for SSCI journals which have cited articles appearing in either Terrorism and Political Violence or Studies in Conflict and Terrorism. A search was performed in the Web of Science database for articles published in 2007, 2008, 2009 which contained references to either journal. ${ }^{14}$ The results included the bibliographic information, cited references, and assigned subject categories for each article. Only the articles appearing in SSCI journals were extracted using the 2009 list of fully covered SSCI journals. Data was gathered for the number of unique citations to either Terrorism and Political Violence or Studies in Conflict and Terrorism in each SSCI journal article.

\section{Findings: Cited References}

The data indicated a close interdependence between Terrorism and Political Violence and Studies in Conflict and Terrorism. Data extrapolated from table 1 reveal that 188 $(10 \%)$ of the total 1,954 references were cross-references (cross-cites) between the two journals. If one adds in the self-cites, 344 , fully 27 percent, of the cited references are attributed to either Terrorism and Political Violence or Studies in Conflict and Terror- ism. The remaining 1,422 cited references are dispersed among 325 SSCI journals. The wide dispersal of the supporting literature is an indication of the multidisciplinary nature of terrorism research.

One approach to narrow the 325 SSCI journals into a workable core list would be to rank them in descending order by number of cited references. The JCR Citing Journal Listings were inadequate for this study because of the following limitations: JCR includes cited references from non-SSCI publications, and it does not cumulate cited references over a period of years. ${ }^{15}$ Since JCR's Citing Journal Listing is not complete, it is possible that an omitted journal title in one or more of the three years could have more cumulative cited references than a journal title that does appear on the list in those same years. JCR does not provide an accurate assessment of cited references for multiple year studies. The inverse problem can also occur. A journal title could be included in the Citing Journal Listing on account of it having a significant number of cited references in a given year, such as having cited references in special issues, but not be cited again for several years, if ever.

For this study, given the multidisciplinary nature of terrorism research, an article on an esoteric topic could appear in either Terrorism and Political Violence or Studies in Conflict and Terrorism with a significant number of references to sources that may not be cited for years, if ever again, in these two publications. To guard against this type of anomaly, the authors applied a criterion that a cited reference journal must appear in at least two of the three years studied. 
The results of the application of the criterion are displayed in table 2, which does not include self-cites and cross-cites in either Terrorism and Political Violence or Studies in Conflict and Terrorism. The application of the criterion to cited references appearing in Terrorism and Political Violence resulted in 50 journals, accounting for 283 cited references. For Studies in Conflict and Terrorism, there were 105 journals, accounting for 775 references. Limiting the results to those titles that meet the criterion in both journals results in 37 titles, accounting for 759 of the cited references.

The $80 / 20$ rule is widely accepted as a measurement tool in collection studies. In general the $80 / 20$ rule, as applied to library collection studies, states that 20 percent of the publications account for 80 percent of the results whether they are book circulations, periodical uses, citation studies, or other types of library use data. Nisonger reviewed the history of the use of the $80 / 20$ rule in studies designed to identify core journals. He concluded that the $80 / 20$ rule can be successfully used to identify core journals in studies based on either use or citation data. However, he also noted that the percentages do not and are not expected to work out precisely and that variables including the journals' subject matter influence the percentages. ${ }^{16}$ As indicated in table 2 , the 37 journals represent 11 percent of the journals and account for 53 percent (759) of the cited references. However, Terrorism and Political Violence and Studies in Conflict and Terrorism were excluded from the initial analysis because the primary purpose was to identify additional core titles. To properly apply the
$80 / 20$ rule, cross-cites derived from table 1 (188) should be added back into the results. The resulting 12 percent (39) of the titles from table 2 account for 59 percent (947) of the cited references from table 1 . While the percentages deviate considerably from the $80 / 20$ pattern, they still indicate in this study that relatively few journals account for a high percentage of the cited references - a conclusion consistent with the basic premise of the $80 / 20$ rule that relatively few titles account for a high percentage of uses.

The complete list of the 39 journals matching the criterion with the number of cited references accounted for by each is displayed in table 3 . This comprises the core list of journals based on this study.

Here are three caveats to consider:

1) Several of the major journals in the social science disciplines appear on the core list, such as American Political Science Review, American Sociological Review, and Political Science Quarterly. The authors assume that most of the cited references to articles appearing in these journals were for theoretical or methodological reasons rather than references to articles on terrorism studies proper. This assumption is supported by the journal listing in table 6, which presents SSCI journals most heavily citing Terrorism and Political Violence and Studies in Conflict and Terrorism. None of the major journals referenced above appear on this list. If those journals were publishing articles (on even a semiregular basis) concerning terrorism, we would expect them to appear on the list. The fact that they do not appear on the list is an indication that they are not publishing many articles dealing directly with terror-

TABLE 2

Journal Titles and Cited Refs without Self-cites and Cross-cites

\begin{tabular}{|l|c|c|c|c|c|c|}
\hline & $\begin{array}{c}\text { Journals } \\
\text { Cited in } \\
\text { TPV }\end{array}$ & $\begin{array}{c}\text { Cited } \\
\text { References } \\
\text { in TPV }\end{array}$ & $\begin{array}{c}\text { Journals } \\
\text { Cited in } \\
\text { SCT }\end{array}$ & $\begin{array}{c}\text { Cited } \\
\text { References } \\
\text { in SCT }\end{array}$ & $\begin{array}{c}\text { Combined } \\
\text { Journals } \\
\text { de-duped }\end{array}$ & $\begin{array}{c}\text { Combined } \\
\text { Cites }\end{array}$ \\
\hline Total & 156 & 425 & 274 & 997 & 325 & 1,422 \\
\hline $\begin{array}{l}\text { Criterion } \\
\text { Applied }\end{array}$ & $\begin{array}{c}50(32 \% \\
\text { of total })\end{array}$ & $\begin{array}{c}283(67 \% \\
\text { of total })\end{array}$ & $\begin{array}{c}105(38 \% \\
\text { of total })\end{array}$ & $\begin{array}{c}775(78 \% \\
\text { of total })\end{array}$ & $\begin{array}{c}37(11 \% \\
\text { of total })\end{array}$ & $\begin{array}{c}759(53 \% \\
\text { of total }) *\end{array}$ \\
\hline
\end{tabular}

*Total from the 37 combined journals deduped. 
ism studies. In any case, the appearance of the journals on this list would not be of much assistance to collection development librarians seeking to enhance their terrorism research collections, since most academic libraries would already have these journals in their collections.

2) The core list is based on journals fully covered in SSCI. During the data collection process, the authors identified several academic journals that met the two-year criterion but are not included on the core list because they are not covered in SSCI. For example, Parameters: The US Army War College Quarterly (with 19 cited references) and Foreign Policy (with 21 cited references). That these journals were not covered is not surprising given that coverage in SSCI of Terrorism and Political Violence and Studies on Conflict and Terrorism is relatively recent.

3) SSCI does not fully cover professional or trade journals, and yet these types of journals may be very important to academics engaged in terrorism research. For example, this study found Jane's Intelligence Review had met the twoyear criterion with 40 cited references, but since it is not covered by SSCI is not included on the list.

\begin{tabular}{|l|c|l|c|}
\hline \multicolumn{4}{|c}{ TABLE 3} \\
Core List of Journals \\
\hline Titles & Cites & Titles & Cites \\
\hline $\begin{array}{l}\text { Terrorism and Political Violence } \\
\text { (w/o self-cites) }\end{array}$ & 108 & Current History & 14 \\
\hline Journal of Conflict Resolution & 87 & $\begin{array}{l}\text { International Journal of Middle } \\
\text { East Studies }\end{array}$ & 12 \\
\hline $\begin{array}{l}\text { Studies in Conflict and Terrorism } \\
\text { (w/o self-cites) }\end{array}$ & 80 & $\begin{array}{l}\text { Annals of the American Academy } \\
\text { of Political and Social Science }\end{array}$ & 11 \\
\hline Foreign Affairs & 72 & Journal of Contemporary History & 11 \\
\hline International Security & 56 & Journal of Democracy & 9 \\
\hline American Political Science Review & 54 & Middle East Journal & 9 \\
\hline International Organization & 35 & Annual Review of Political Science & 8 \\
\hline Journal of Peace Research & 34 & Journal of Modern African Studies & 8 \\
\hline Washington Quarterly & 32 & $\begin{array}{l}\text { Journal of Personality and Social } \\
\text { Psychology }\end{array}$ & 8 \\
\hline Comparative Politics & 31 & Middle Eastern Studies & 8 \\
\hline Survival & 30 & Annual Review of Sociology & 7 \\
\hline World Politics & 26 & Bulletin of the Atomic Scientists & 7 \\
\hline $\begin{array}{l}\text { American Journal of Political } \\
\text { Science }\end{array}$ & 24 & $\begin{array}{l}\text { Cambridge Review of International } \\
\text { Affairs }\end{array}$ & 7 \\
\hline International Studies Quarterly & 22 & International Affairs & 6 \\
\hline Political Psychology & 20 & Criminology & 6 \\
\hline American Sociological Review & 19 & New Republic & 6 \\
\hline Political Science Quarterly & 19 & Politics and Society & Rationality and Society \\
\hline American Journal of Sociology & & American Historical Review & 6 \\
\hline Middle East Policy & 14 & & 6 \\
\hline Asian Survey & & 6 \\
\hline & & \\
\hline
\end{tabular}




\begin{tabular}{|l|c|c|c|}
\hline \multicolumn{4}{|c|}{ TABLE 4 } \\
Citing References to TPV and SCT in SSCI Journals \\
\hline & Cites to TPV & Cites to SCT & Combined Cites \\
\hline Total & 788 & 670 & 1,458 \\
\hline Without Self-cites & $622(79 \%$ of total $)$ & $484(72 \%$ of total $)$ & $1,106(76 \%$ of total $)$ \\
\hline $\begin{array}{l}\text { Without Self-cites } \\
\text { and Cross-cites }\end{array}$ & $520(66 \%$ of total $)$ & $407(61 \%$ of total $)$ & $927(64 \%$ of total $)$ \\
\hline
\end{tabular}

All three of these caveats are attributed to the methodology employed by the authors of this study and are an indication of the types of limitations that need to be recognized with the development of core journal lists. The authors stand by their methodology but remind collection development librarians that any core list should be considered imperfect.

\section{Findings: Citing References}

There is a related but somewhat different purpose in the citing references portion of this study. Here the principal concern was to identify SSCI journals that most heavily cited Terrorism and Political Violence and Studies in Conflict and Terrorism. SSCI assigns a subject (or multiple subjects) to each of its journals. The authors thought that the subjects as applied to the citing journals might be useful in providing some guidance to collection development librarians in the social sciences, with the understanding that this information could be used within the context of the particular research interests at any given institution. The authors also compared the cited journal list in table 3 with the list of the most heavily citing journals in an attempt to identify journals in which there was a reciprocal citing pattern with Terrorism and Political Violence and Studies in Conflict and Terrorism.
Unlike the JCR Citing Journal Listing, the JCR Cited Journals Listing is composed of SSCI journals only but is still incomplete. ${ }^{17}$ To get complete journal listing data, the authors ran a search in the Web of Science database.

As indicated in the methodology section, the initial results, as displayed in table 4 , are based on a search for references to either Terrorism and Political Violence or Studies in Conflict and Terrorism as they appeared in the cited references to articles published in 2007, 2008, or 2009. Table 4 provides a breakdown of the cited references to Terrorism and Political Violence and Studies in Conflict and Terrorism, as well as self-cite and cross-cite information, which shows there are 927 cited references to either Terrorism and Political Violence or Studies in Conflict and Terrorism appearing in other SSCI journals.

As indicated in table 5, 166 SSCI journals cited Terrorism and Political Violence a total of 520 times over the three-year period and 152 SSCI journals cited Studies in Conflict and Terrorism 407 times over the same time period. Removing the duplicate journal titles from each list yielded 243 unique titles responsible for the 927 citing references. To identify those SSCI journals most impacted by Terrorism and Political Violence and Studies in Conflict and Terrorism, the 243 titles

\begin{tabular}{|l|l|c|c|c|c|c|}
\hline \multicolumn{7}{|c|}{ TABLE 5 } \\
\hline & $\begin{array}{c}\text { Journals That } \\
\text { Cite TPV }\end{array}$ & $\begin{array}{c}\text { TPV Citing } \\
\text { References }\end{array}$ & $\begin{array}{c}\text { Journals That } \\
\text { Cite SCT }\end{array}$ & $\begin{array}{c}\text { SCT Citing } \\
\text { References }\end{array}$ & $\begin{array}{c}\text { Combined } \\
\text { Journals }\end{array}$ & $\begin{array}{c}\text { Combined } \\
\text { Cites }\end{array}$ \\
\hline Total & 166 & 520 & 152 & 407 & 243 & 927 \\
\hline $\begin{array}{l}\text { Meets } \\
\text { Criterion }\end{array}$ & $\begin{array}{c}24(14 \% \\
\text { of total })\end{array}$ & $\begin{array}{c}206(40 \% \\
\text { of total })\end{array}$ & $\begin{array}{c}33(22 \% \\
\text { of total })\end{array}$ & $\begin{array}{c}167(41 \% \\
\text { of total })\end{array}$ & $\begin{array}{c}11(5 \% \\
\text { of total })\end{array}$ & $\begin{array}{c}225(24 \% \\
\text { of total }) *\end{array}$ \\
\hline * Total from the 11 combined journals deduped. \\
\hline
\end{tabular}




\begin{tabular}{|l|c|}
\hline \multicolumn{2}{|c|}{ TABLE 6 } \\
Citing Journals to TPV and SCT \\
\hline Title & $\begin{array}{c}\text { Citing } \\
\text { References }\end{array}$ \\
\hline Studies in Conflict and Terrorism & * \\
\hline Terrorism and Political Violence* & 102 \\
\hline Security Studies & 77 \\
\hline Security Dialogue & 48 \\
\hline International Security & 41 \\
\hline Journal of Conflict Resolution & 29 \\
\hline Conflict Management and Peace Science & 23 \\
\hline International Studies Quarterly & 14 \\
\hline British Journal of Political Science & 13 \\
\hline Journal of Strategic Studies & 13 \\
\hline Political Psychology & 12 \\
\hline Criminology & 7 \\
\hline Defence and Peace Economics & 5 \\
\hline *Without self-cites. & \\
\hline
\end{tabular}

Terrorism and Political Violence and Studies in Conflict and Terrorism according to the results of the study.

\section{Subject Impact}

There are 56 subject categories used by SSCI to index SSCI journals listed in its database. Every SSCI journal has at least one SSCI subject category assigned to it. A total of $45(80 \%)$ of those subject categories were represented at least once in the citing journal references. The total number of citing references shown in table 8 refer to the citations appearing in journals to which those SSCI subject categories were assigned. Because many of the identified citing journals have more than one SSCI subject category, the total number of citations $(1,092)$ exceeds the total number of combined cites (927) as shown in table 5.

The data shown in table 8 may assist citing references to both journals. An SSCI journal that does not routinely publish articles on terrorism might have a special issue devoted to the topic or have a random article with a high number of citations to Terrorism and Political Violence or Studies in Conflict and Terrorism that could distort the results. To guard against the possibility of the same type of anomaly discussed in the analysis of the cited references section of this study, the authors employed the same two-year requirement criterion. Applying the criterion narrowed the results to 24 titles with 206 references to Terrorism and Political Violence and 33 titles with 167 citations to Studies in Conflict and Terrorism. When the results were further restricted to journals that met the two-year criterion for both Terrorism and Political Violence and Studies in Conflict and Terrorism, 11 journal titles were left, which accounted for 225 (24\%) of the citing references. Those titles are listed in table 6.

Table 7 shows a list of journals that appear in both table 6 and table 3 . These titles represent the SSCI journals that show a reciprocal citing pattern with social science collection development librarians in academic program areas that include these subject categories. This may be a factor in helping them determine the value of adding Terrorism and Political Violence and Studies in Conflict and Terrorism to their collections and, by inference, the importance of terrorism research in their fields.

\section{Conclusion}

The study produced a suggested core list of 39 social science journals supporting the

\begin{tabular}{|l|}
\multicolumn{1}{|c|}{ TABLE 7} \\
Common Journal List
\end{tabular}


study of terrorism, which provides useful information to collection development librarians who may want to include more resources pertaining to the study of terrorism. The authors hope that this study can help clarify and improve upon previous studies that used citation data analyses to inform collection development decisions.
While using data from JCR's Citing Journals Listing and Cited Journals Listing may prove useful in determining gross citation numbers, JCR's limited display of the cited and citing journal lists inhibit detailed analyses of comprehensive citation patterns for each citing and cited journal. The authors thought that hand-checking every citation

\begin{tabular}{|c|c|c|c|}
\hline \multicolumn{4}{|c|}{$\begin{array}{c}\text { TABLE } 8 \\
\text { SSCI Subject Categories of Citing Journals* }\end{array}$} \\
\hline Subject Category & $\begin{array}{l}\text { No. of Cites } \\
\text { to TPV or SCT }\end{array}$ & Subject Category & $\begin{array}{l}\text { No. of Cites } \\
\text { to TPV or SCT }\end{array}$ \\
\hline Political Science & 236 & Urban Studies & 8 \\
\hline International Relations & 227 & Ethnic Studies & 6 \\
\hline Criminology \& Penology & 77 & Linguistics & 5 \\
\hline Psychology, Social & 72 & Psychology, Applied & 5 \\
\hline Sociology & 59 & Women's Studies & 5 \\
\hline Economics & 41 & Cultural Studies & 4 \\
\hline Psychology, Clinical & 37 & $\begin{array}{l}\text { Public, Environmental, \& } \\
\text { Occupational Health }\end{array}$ & 4 \\
\hline Law & 33 & Social Work & 4 \\
\hline $\begin{array}{l}\text { Social Sciences, } \\
\text { Interdisciplinary }\end{array}$ & 31 & $\begin{array}{l}\text { Education \& Educational } \\
\text { Research }\end{array}$ & 3 \\
\hline $\begin{array}{l}\text { Psychology, } \\
\text { Multidisciplinary }\end{array}$ & 26 & Ergonomics & 3 \\
\hline Area Studies & 24 & Demography & 2 \\
\hline Planning \& Development & 24 & Health Policy \& Services & 2 \\
\hline Geography & 19 & $\begin{array}{l}\text { Hospitality, Leisure, Sport } \\
\& \text { Tourism }\end{array}$ & 2 \\
\hline Social Issues & 17 & Nursing & 2 \\
\hline Anthropology & 16 & Operations Research & 2 \\
\hline Business & 13 & Social Sciences, Biomedical & 2 \\
\hline Communication & 13 & $\begin{array}{l}\text { Social Sciences, } \\
\text { Mathematical Methods }\end{array}$ & 2 \\
\hline Psychiatry & 13 & Transportation & 2 \\
\hline Public Administration & 11 & Business, Finance & 1 \\
\hline Management & 10 & Ethics & 1 \\
\hline Environmental Studies & 9 & History of Social Sciences & 1 \\
\hline $\begin{array}{l}\text { Information Science \& } \\
\text { Library Science }\end{array}$ & 9 & $\begin{array}{l}\text { Industrial Relations \& } \\
\text { Labor }\end{array}$ & 1 \\
\hline History & 8 & & \\
\hline
\end{tabular}


to and in Terrorism and Political Violence and Studies in Conflict and Terrorism from 2007 through 2009 was the best way to see just how broad or limited the scope of citation patterns actually were during that period. Since terrorism studies is acknowledged as a multidisciplinary research area, the authors endeavored to show the impact that terrorism has had on established social science journals, as shown in table 6 . This reflects the trend for more academic focus on the topic, whether in the form of academic programs or research centers. The study of terrorism, while lacking the traditional attributes of a formal academic discipline, is of increasing importance. The cross-citing patterns of the two subject journals used in this study with the other 11 SSCI journals indicate the increasing value of formal terrorism research to other more well-established social science disciplines such as international relations, political science, criminology, psychology, sociology, and economics. In a post-9/11 world, terrorism has taken a place of prominence in popular and political conscience, and it is time for its formal study to take its place of prominence in the collective conscience of the Academy. Library collections should be adapted accordingly.

\section{Notes}

1. Edna O.F. Reid, "Evolution of a Body of Knowledge: An Analysis of Terrorism Research," Information Processing \& Management 33, no. 1 (1997): 91-106.

2. Avishag Gordon, "Terrorism and Knowledge Growth: A Database and Internet Analysis," in Research on Terrorism: Trends, Achievements and Failures, ed. Andrew Silke (London: Frank Cass, 2004): 104-18; Andrew Silke, "The Road Less Traveled: Recent Trends in Terrorism Research," in Research on Terrorism: 186-214.

3. Edna F. Reid and Hsinchun Chen, "Mapping the Contemporary Terrorism Research Domain," International Journal of Human-Computer Studies 65 (2007): 42-56.

4. Silke, "The Road Less Traveled."

5. Avishag Gordon, "The Peripheral Terrorism Literature: Bringing it Closer to Home," Scientometrics 62, no. 3 (2005): 403-414; Avishag Gordon, "Transient and Continuent Authors in a Research Field: The Case of Terrorism," Scientometrics 72, no. 2 (2007): 213-24.

6. Gordon, "Transient and Continuent Authors," 218.

7. Michael W. Giles and James C. Garand, "Ranking Political Science Journals: Reputational and Citational Approaches," PS: Political Science and Politics 40, no. 1 (Oct. 2007): 741-51.

8. Katherine Corby, "Constructing Core Journal Lists: Mixing Science and Alchemy," portal: Libraries and the Academy 3, no. 2 (2003): 207-17.

9. Corby, "Constructing Core Journal Lists," 209; Patrick Doreian, "On the Ranking of Psychological Journals," Information Processing and Management 25, no. 2 (1989): 205-14.

10. Thomas E. Nisonger, "Journals in the Core Collection: Definition, Identification, and Applications," The Serials Librarian 51, no. 3/4 (2007): 51-73.

11. John M. Budd, "Higher Education Literature: Characteristics of Citation Patterns," Journal of Higher Education 61, no. 2 (1990): 84-97.

12. Thomas Weissinger, "The Core Journal Concept in Black Studies," Journal of Academic Librarianship 36, no. 2 (2010): 119-24.

13. Thomson Reuters, "Journal Search: Social Sciences Citation Index," available online at www.thomsonscientific.com/cgi-bin/jrnlst/jloptions.cgi?PC $=$ J [accessed Spring 2011]. At the time we collected our data, the database reflected holdings through 2009.

14. There is some variance in the way the journals are abbreviated in the cited references in the exported list of citations from Web of Science, so care was taken in the construction of the search strategy. Terrorism and Political Violence may appear truncated as "TERRORISM POLITICAL" or "TERROR POLIT VIOLENC" and Studies in Conflict and Terrorism may appear as "STUDIES CONFLICT TER" or "STUD CONFL TERROR."

15. JCR's Citing Journal Listing includes the publication source information for cited references appearing in Terrorism and Political Violence and Studies in Conflict and Terrorism.

16. Thomas E. Nisonger, "The ' $80 / 20$ Rule' and Core Journals," Serials Librarian 55, no.1-2 (2011): 62-84.

17. JCR's Cited Journal Listing includes the publication source information for citing references in SSCI journals to Terrorism and Political Violence and Studies in Conflict and Terrorism. 


\section{Current APS Memoirs}

The House of Barnes:

The Man, The Collection,

The Controversy

Neil L. Rudenstine

Vol. 266 - \$45 - Cloth

ISBN: 978-0-87169-266-5

2012 J.F. LEWIS AWARD WINNER

Astronomy in the

Maya Codices

Harvey M. Bricker and

Victoria R. Bricker

Vol. 265 - \$75 • Cloth

ISBN: 978-0-87169-265-8

2011 J.F. LEWIS AWARD WINNER

Peter Collinson and the

Eighteenth-Century

Natural History Exchange

Jean O'Neill and

Elizabeth P. McLean

Vol. 264 - \$75 • Cloth

ISBN: 978-0-87169-264-1

Visual Mechanic Knowledge:

The Workshop Drawings of Isaac

Ebenezer Markham (1795-1825),

New England Textile Mechanic

David J. Jeremy and

Polly C. Darnell

Vol. 263 - \$60 • Paper

ISBN: 978-0-87169-263-4

POLAR HAYES: The Life and

Contributions of Isaac Israel

Hayes, M.D.

Douglas W. Wamsley

Vol. 262 - \$75.00 • Cloth

ISBN: 978-0-87169-262-7

Patriot-Improvers, Volume III

Whitfield J. Bell and

Charles Griefenstein

Vol. 228 - \$60.00 - Cloth

ISBN: 978-0-87169-228-3

Volume One (1997) -- \$40

Volume Two (1999) -- \$40

Volume Three (2010) -- \$60

Three-volume set -- \$125

\section{Current APS Transactions}

CIRCLING THE SQUARE: How the

Conquest Altered the Shape of

Time in Mesoamerica

Anthony Aveni

Vol. 102, Part 5 - \$35 • Paper

ISBN: 978-1-60618-025-9

Pictograph to Alphabet—and Back:

Reconstructing the Pictographic

Origins of the Xajil Chronicle

Robert M. Hill II

Vol. 102, Part 4 - \$35 • Paper

ISBN: 978-1-60618-024-2

Johann Gustav Droysen: History of

Alexander the Great

Translated from the German

by Flora Kimmich

Vol. 102, Part 3 - \$35 • Paper

Review of Atlantic and Eastern

Pacific Anthiine Fishes

William D. Anderson, Jr. and

Phillip C. Heemstra

Vol. 102, Part 2 - \$35 • Paper

ISBN: 978-1-60618-022-8

Both English and Latin: Bilingualism and Biculturalism in Milton's

Neo-Latin Writings

Estelle Haan

Vol. 102, Part 1 - \$35 • Paper

ISBN: 98-1-60618-021-1

KRONOS, SHIVA, AND ASKLEPIOS

Studies in Magical Gems and

Religions of the Roman Empire Attilio Mastrocinque

Vol. 101, Part 5 - \$35 • Paper

ISBN: 1-60618-015-0

Figuring History

Lionel Gossman

Vol. 101, Part 4 - \$35 • Paper

ISBN: 1-60618-014-3

Peiresc's History of Provence

Antiquarianism and the Discovery of a Medieval Mediterranean

Peter N. Miller

Vol. 101, Part 3 - \$35 • Paper

ISBN: 978-1-60618-013-6
ISBN: 978-1-60618-023-5

Treason on Trial in Revolutionary

Pennsylvania: The Case of John

Roberts, Miller

David W. Maxey

Vol. 101, Part 2 - \$35 • Paper

ISBN: 978-1-60618-012-9

The Bookrunner: A History of Inter-

American Relations-Print, Politics, and Commerce in the United States and Mexico, 1800-1830

Nancy Vogeley

Vol. 101, Part 1 - \$35 • Paper

ISBN: 978-1-60618-011-2

\section{Lightning Rod Press Titles}

The Life of C.S. Rafinesque:

A Man of Uncommon Zeal

Charles Boewe

Vol. 7 - \$35 • Paper

ISBN: 978-1-60618-922-1

CLIMATE CRISES IN

HUMAN HISTORY

A. Bruce Mainwaring,

Robert Giegengack, and

Claudio Vita-Finzi (eds.)

Vol. 6 - \$35 • Paper

ISBN: 978-60618-921-4

Darwin's Disciple:

George John Romanes,

A Life in Letters

Joel S. Schwartz

Vol. 5 - \$60 • Paper

ISBN: 978-1-60618-920-7

"TO DO JUSTICE TO HIM \&

MYSELF": Evert Wendell's

Account Book of the Fur Trade with

Indians in Albany,

New York, 1695-1726

Edited and Translated by

Kees-Jan Waterman with

linguistic information by

Gunther Michelson

Vol. 4 - $\$ 50$ • Paper

ISBN: 978-1-60618-912-2

104 South Fifth Street

AMERICAN

PHILOSOPHICAL SOCIETY

Philadelphia, PA 19106-3387

(Tel) 215-440-3425

(Fax) 215-440-3450

BOOK ORDERS: Please contact our fulfillment service-

Diane Publishing Co., P.O. Box 617, Darby, PA 19023 (phone 800-782-3833; fax 610-461-6130).

Online orders may be sent to orders@dianepublishing.net.

See our website for recent catalogs and backlist: www.aps-pub.com. 